\title{
SUPPLY AND DEMAND ANALYSIS OF STARS HOTEL IN BANDUNG
}

\author{
${ }^{1}$ Heru Kurniadi, MM.Par \\ ${ }^{2}$ Dr. Lien Maulina, M.Pd \\ ${ }^{3}$ Andre Hernowo, M.Si, AK \\ 1,2,3 Post Graduate Program Bandung Institute of Tourism \\ Bandung,Indonesia \\ herukurniadi@yahoo.com
}

ABSTRACT

\begin{abstract}
This study was created based on analysis for supply and demand in stars hotel in Bandung, this analysis limited to hotels that have 2,3 , and 4 star, the consideration was come up with the reason to make easier on the process of the analysis, from supply and demand analysis was also found the point of equilibrium to justify the condition of market, from the conclusion of the
\end{abstract}

\section{INTRODUCTION}

Bandung is the third largest city in Indonesia after Jakarta and Surabaya by population. Bandung is still a favorite city for tourist destination, the increase in the number of tourists in the city of Bandung is prove by the national bureau of statistic said that data of domestic tourists and foreign tourists coming to the city of Bandung in 2015. From the data of tourist visits to Bandung indicate that the rate of flow of tourists who enter Bandung, especially during weekends and long holidays is on the spotlight and become serious in an effort to accommodate the needs of the tourists, one of which is infrastructure in Bandung is hotel, no matter it is stars or non-star hotel classification it have a demand to the needs and interests and also travel budget of the tourists. The availability of infrastructure for tourism activities in Bandung (supply) indicated cannot balance the needs of the tourists who come to Bandung (demand). analysis it can be used for a reason to make a feasibility study in investment for accommodation business without a stars rating hotel in Bandung, and the accommodation to be consider is homestay in Bandung.

Keywords: Hotel supply and demand, equilibrium point, homestay feasibility study

Associated with tourism activities located in Bandung. Hotel consisting of various types, ranging from budget hotels to fivestar hotel, or are currently classified into a star and non-star hotel. The tourists who come to Bandung tend to prefer to stay at five-star hotel that is close to their travel destinations, but unfortunately not all tourists can be accommodated, because the number of rooms available is limited, especially during the weekends.

From the hotel reservation in Bandung in 2015 Source: Riung Priangan/Casa Grande Bandung 2015 found that for 4-star hotels reservations on weekday or weeknight obtained gap of $40 \%$, so 4 star hotel in Bandung still offers enough rooms for the tourists, but when we look at the gap that occurs on a weekend the figure reached $17 \%$, so 4-star hotel in Bandung still have shortage of 79210 rooms supply compared to the demand of 573490 rooms. Found out 
that not much different for the 3-star hotel, the number of reservations in Bandung during the weekday has a gap of $40 \%$, so the 3 star hotel still offers enough for the tourists, but the gap that occurred during the weekend of $-10 \%$ means the 3-star hotel in Bandung still has a shortfall of 117582 rooms supply.

The number of hotel reservation in 2 star hotel with levels of inequality during the weekday by $45 \%$, so 2 stars hotel still offers pretty good number of supply for the tourists, but the gap that occurred during the weekend of $-22 \%$ means 2-star hotel in Bandung still have shortage of 134381 rooms supply. Then, when we reviewed the data of room occupied in 2, 3, and 4 start hotel in Bandung in 2015 (Source: Riung Priangan/Casa Grande Bandung 2015) found that 4 star hotel number of rooms occupied during weekdays obtained gap of $50 \%$, so 4 star hotel in Bandung still offers enough room supply for the tourists , but when we look at the gap that occurs on a weekend the figure decreased by $10 \%$ means that 4 star hotel in Bandung can still provide an offer of 124575 compared with the demand for 121171 rooms .

Found out that not much different for the 3 -star hotel, the number of rooms occupied in Bandung during the weekday has a gap of $60 \%$, a 3 star hotel still offers enough supply rooms for the tourists, but the gap that occurs at the weekend decreased by 5\% means 3 Star Hotels in Bandung still has an offer of 64094 rooms, compared to the demand for 121778 rooms. The number of room occupied in 2 star hotel during the weekday by $40 \%$, so 2 star hotel still offers pretty good supply of rooms for the tourists, but the gap that occurred during the weekend is $0 \%$ means 2-star hotel in Bandung do not have more availability of rooms regarding to a reservation rate of $22 \%$ more than the available rooms. Based on what already described above, the focus on the problems that arise and are addressed in this study, is: How the Analysis of supply and demand of stars hotel Bandung in 2015.

\section{METODOLOGY}

\section{A. Research Objective}

Objectives to be achieved by the author through this study is to investigate, assess and get a picture and information about the analysis of the pre - feasibility study for accommodation in Bandung, based on the formulation of the problem above, the purpose of the research in this thesis is to find out:

1. The level of needs of hotel rooms in Bandung categorized on the classification and limited to 2, 3, and 4 stars hotel in 2015.

2. The level of room availability in Bandung categorized and limited to 2, 3, and 4 stars hotel in 2015.

3 . The decision to stay at hotel with classification and limited to 2, 3, and 4 stars hotel in 2015.

\section{B. Methods and Techniques}

This study uses a qualitative method by observing the level of tourists staying in Bandung, and observed the demand for hotel in Bandung with a classification and limited to 2, 3, and 4 stars hotel,.

\section{RESULTS AND DISCUSSION}

\section{A. Demand analysis}

Stars hotel is considered to be appropriate to be set amidst in Bandung because it fits with the character of the city hotel, hotel which is located in the center of the city usually accommodate guests whose aim business or service. The location chosen should be have a good distances to offices or business areas located in Bandung.

2 star hotel in Bandung has a substantial demand, other than the price is affordable and have easy accessible to various location in the city, the other thing is easy 
to book through online travel agents, it is become excellent distribution channel to introduce and sell products 2 star accommodation in Bandung .

3-star hotel has a strength of market position in Bandung, which is quite high with consideration of price, amenities and an ideal location, then this type is superior in terms of occupancy levels and length of stay of tourists staying in Bandung, in addition to the many choices of this hotel there are a couple of excellence offered from this particular establishment in Bandung.

4-star hotels have a different segmenting, it makes a 4 star hotel in Bandung can be superior in its class, besides the numbers are not too many, 4-star hotel is in a great demand in various activities, especially MICE, 4-star hotel is much wanted from the tourist as a place to stay and a place of meetings, events, and have a great location in Bandung, only some of 4 star hotels that can provide flexibility when organizing this case because of the limited number of 4-star hotel in Bandung.

The demand that exists today it is wise for the construction of a 4 star hotel in Bandung can be analyzed according to the function of demand and supply, is expected that 4-star hotel can ideally accommodate the needs of guests who stay and conduct their activities in Bandung.

From the the level of demand for 2-starhotel in Bandung, the analysis raises the average occupancy rate above $32 \%$ up to $60 \%$ and average prices ranging from Rp.237.290, - up to Rp.367.000, - there are two hotels as a comparison of the level of occupancy and the highest price and comparison of the low occupancy levels at the lowest price, is Asmila Boutique Hotels have highest ranked of the occupancy rate and prices, and vice versa is Hadiat's hotels are getting the lowest rank of the occupancy rate and prices.
There are some name that has the level of demand and prices offered vary, there are some distribution of cluster request to figure high demand at the low prices, high demand at the high prices, and low demand at the high price, and last is low demand at the low price, the hotels are:

Tabel 1

\section{Demand level 2 Star Hotels in Bandung}

\begin{tabular}{cccc}
\hline $\begin{array}{c}\text { High Demand at a } \\
\text { Low Price }\end{array}$ & $\begin{array}{c}\text { Alam } \\
\text { Perma } \\
\mathrm{i}\end{array}$ & $57.58 \%$ & 259,900 \\
\hline $\begin{array}{c}\text { High Demand at a } \\
\text { High Prices }\end{array}$ & $\begin{array}{c}\text { Asmila } \\
\text { Butik }\end{array}$ & $60.20 \%$ & 367,003 \\
\hline $\begin{array}{c}\text { Low Demand at a } \\
\text { High Price }\end{array}$ & Provence & $39.57 \%$ & 325,720 \\
\hline $\begin{array}{c}\text { Low demand at a } \\
\text { Low Price }\end{array}$ & Hadiat's & $32.50 \%$ & 237,290 \\
\hline
\end{tabular}

The level of demand for 3-star hotel in Bandung, the data analysis raises the average occupancy rate at the beginning of a $29 \%$ to $54 \%$ and average prices ranging from $\mathrm{Rp} 285.390$ up to $\mathrm{Rp} 564.942$, there are two hotels as a comparison of the level of occupancy and the highest price is Ibis Style Braga have the highest ranked of the occupancy rate and prices, and vice versa is Imperium Hotels get the lowest rank of the occupancy rate and prices.

Tabel 2

\section{Demand level 3 Star Hotels in Bandung}

\begin{tabular}{cccc}
\hline $\begin{array}{c}\text { High Demand at a } \\
\text { Low Price }\end{array}$ & Bumi Asih Jaya & $47.56 \%$ & 285,390 \\
\hline $\begin{array}{c}\text { High Demand at a } \\
\text { High Prices }\end{array}$ & Ibis Style Braga & $54.69 \%$ & 564,942 \\
\hline $\begin{array}{c}\text { Low Demand at a } \\
\text { High Price }\end{array}$ & Ibis & $32.50 \%$ & 470,370 \\
\hline $\begin{array}{c}\text { Low demand at a } \\
\text { Low Price }\end{array}$ & Imperium & $29.86 \%$ & 285,390 \\
\hline
\end{tabular}

The level of demand for a 4-star hotel in Bandung, the data analysis raises the average occupancy rate starts from $38 \%$ up to $69 \%$ and average prices ranging from Rp 295.000 up to Rp 564.942 there are two hotels as a comparison of the level of occupancy and the highest price is Galeri Ciumbuleuit that have highest ranked of the occupancy and highest price, 
and vice versa is The Rich Royale getting the lowest rank of the occupancy rate and the lowest price.

Tabel 3

\section{Demand Level 4 Star Hotels in Bandung}

\begin{tabular}{cccc}
\hline $\begin{array}{c}\text { High Demand at } \\
\text { a Low Price }\end{array}$ & Horison & $69.42 \%$ & 403,177 \\
\hline $\begin{array}{c}\text { High Demand at } \\
\text { a High Prices }\end{array}$ & $\begin{array}{c}\text { Galeri } \\
\text { Ciumbuleuit }\end{array}$ & $69.47 \%$ & 564,942 \\
\hline $\begin{array}{c}\text { Low Demand at } \\
\text { a High Price }\end{array}$ & $\begin{array}{c}\text { Arion Swiss } \\
\text { Bell }\end{array}$ & $39.86 \%$ & 410,377 \\
\hline $\begin{array}{c}\text { Low demand at } \\
\text { a Low Price }\end{array}$ & Rich Royale & $38.61 \%$ & 295,441 \\
\hline
\end{tabular}

\section{B. Supply analysis}

2-star hotel in Bandung offers, starting from an average occupancy of $32.50 \%$ to $60.20 \%$ and average prices ranging from $\mathrm{Rp} 235.207$ up to $\mathrm{Rp} 371.303$ there are four hotels as a comparison of the average occupancy rate and the average price of this 2 -star hotel, the hotel is Atlantic City

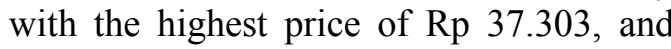
Royal Palace with the lowest price of $\mathrm{Rp}$ 235.207, and that the highest average occupancy Boutique Asmila $60.20 \%$, and the lowest occupancy is Hadiat 's at $32.50 \%$.

\section{Tabel 4}

\section{Supply level 2 Star Hotels in Bandung}

\begin{tabular}{cccc}
\hline $\begin{array}{c}\text { High Supply } \\
\text { at a Low Price }\end{array}$ & Kedaton & $176.41 \%$ & $1,798,983$ \\
\hline $\begin{array}{c}\text { High Supply } \\
\text { at a High Price }\end{array}$ & $\begin{array}{c}\text { Asmila } \\
\text { Butik }\end{array}$ & $177.59 \%$ & $1,935,040$ \\
\hline $\begin{array}{c}\text { Low Supply at } \\
\text { a High Price }\end{array}$ & Provence & $116.73 \%$ & $1,587,338$ \\
\hline $\begin{array}{c}\text { Low Supply at } \\
\text { a Low Price }\end{array}$ & Hadiat's & $95.88 \%$ & $1,421,045$ \\
\hline
\end{tabular}

3-star hotel in Bandung offers, starting from an average occupancy of $29.86 \%$ to $54.69 \%$ and the average prices ranging from $\mathrm{Rp} 285.390$ up to Rp 564.942 there are three hotels as a comparison of the average occupancy rate and the average price of 3-star hotel, the hotel is Ibis Style Braga with the highest price of Rp 564.942 and Bumi Asih at the lowest price Rp 285.390 and the highest occupancy rate is
Ibis Style Braga of $54.69 \%$, and the lowest occupancy is Imperium with $29.86 \%$.

Tabel 5

Supply level 3 Star Hotels in Bandung

\begin{tabular}{cccc}
\hline $\begin{array}{c}\text { High Supply } \\
\text { at a Low Price }\end{array}$ & Kumala & $121.69 \%$ & $1,436,163$ \\
\hline $\begin{array}{c}\text { High Supply } \\
\text { at a High Price }\end{array}$ & $\begin{array}{r}\text { Ibis Style } \\
\text { Braga }\end{array}$ & $133.99 \%$ & $1,814,100$ \\
\hline $\begin{array}{c}\text { Low Supply at } \\
\text { a High Price }\end{array}$ & Isola Resort & $82.12 \%$ & $2,267,225$ \\
\hline $\begin{array}{c}\text { Low Supply at } \\
\text { a Low Price }\end{array}$ & Imperium & $73.16 \%$ & $1,421,045$ \\
\hline
\end{tabular}

4-star hotels in Bandung offers, starting from an average occupancy of $38.61 \%$ to $69.47 \%$ and average prices ranging from Rp 295.440 up to $\mathrm{Rp} 564.942$ there are four hotels as a comparison of the average occupancy rate and the average price of 4star hotel, the hotel is Galeri Ciumbuleuit with the highest price of Rp 564.942 and Bumi Asih at the lowest price Rp 295.440 and that the highest Rich Royale of $69.47 \%$, and the lowest occupancy is Arion Swiss Bell with $38.61 \%$.

Tabel 6

Supply level 4 Star Hotels in Bandung

\begin{tabular}{cccc}
\hline $\begin{array}{c}\text { High Supply } \\
\text { at a Low Price }\end{array}$ & Horison & $170.08 \%$ & $1,865,500$ \\
\hline $\begin{array}{c}\text { High Supply } \\
\text { at a High Price }\end{array}$ & $\begin{array}{c}\text { Savoy } \\
\text { Homann }\end{array}$ & $169.37 \%$ & $3,174,675$ \\
\hline $\begin{array}{c}\text { Low Supply at } \\
\text { a High Price }\end{array}$ & $\begin{array}{c}\text { Arion } \\
\text { Swissbell }\end{array}$ & $82.12 \%$ & $2,267,225$ \\
\hline $\begin{array}{c}\text { Low Supply at } \\
\text { a Low Price }\end{array}$ & $\begin{array}{c}\text { Galeri } \\
\text { Ciumbuleuit }\end{array}$ & $97.66 \%$ & $2,040,863$ \\
\hline
\end{tabular}

\section{Supply and Demand Analysis (Equilibrium)}

In the level of supply and demand in the 2star hotel in the city of Bandung has a cluster assessment that describes the hotel with the highest bid price is compared with the number of highest demand and the amount of the highest bid, in order to get the average price, the number of requests and the number of offers that balanced can be a point of balance (equilibrium) 2 star hotel in Bandung, the data can be illustrated in the table 7. 
Tabel 7

Level of Supply and Demand Balance 2 Star Hotel in Bandung
Tabel 8

Level of Supply and Demand Balance 3 Star Hotel in Bandung

\begin{tabular}{|c|c|c|c|c|c|c|c|c|c|}
\hline $\begin{array}{l}\text { High Supply at } \\
\text { Low Demand }\end{array}$ & Iadiat's & 13505 & 2949 & 556 & $\begin{array}{l}\text { High Supply at } \\
\text { Low Demand }\end{array}$ & $\begin{array}{l}\text { Ibis } \\
\text { Hotel }\end{array}$ & 221920 & 176715 & 45205 \\
\hline $\begin{array}{l}\text { High Supply at } \\
\text { High Demand }\end{array}$ & Pop Harris & 63875 & 00680 & -36805 & $\begin{array}{c}\text { High Supply at } \\
\text { High Demand }\end{array}$ & $\begin{array}{l}\text { Ibis } \\
\text { Budget }\end{array}$ & 59860 & 65541 & -5681 \\
\hline $\begin{array}{l}\text { Low Supply at } \\
\text { High Demand }\end{array}$ & Tave Hotel & 54750 & 33097 & 8347 & $\begin{array}{l}\text { Low Supply at } \\
\text { High Demand }\end{array}$ & $\begin{array}{l}\text { Ibis } \\
\text { Style }\end{array}$ & 24455 & 32767 & -8312 \\
\hline $\begin{array}{l}\text { Low Supply at } \\
\text { Low Supply }\end{array}$ & Hadiat's & 13505 & 12949 & 556 & $\begin{array}{l}\text { Low Supply at } \\
\text { Low Supply }\end{array}$ & Bilique & 8760 & 32718 & 1927 \\
\hline $\begin{array}{l}\text { Balance Point } \\
\text { (Equlibrium) }\end{array}$ & & 23973 & 36919 & 2946 & $\begin{array}{l}\text { Balance Point } \\
\text { (Equlibrium) }\end{array}$ & & 34645 & 32718 & 1927 \\
\hline
\end{tabular}

In the balance of supply and demand curves 2-star hotel rooms in the city of Bandung, obtained data on the balance point through polynomial regression method which can be explained as follows:

Polynomial Regression in Price

$$
\begin{gathered}
y=-2349.9 x^{2}+72640 x \\
R^{2}=-1.567
\end{gathered}
$$

Polynomial Regression in Demand

$$
\begin{gathered}
y=-131.09 x^{2}+4708.2 x \\
R^{2}=-0.324
\end{gathered}
$$

So the point of this balance may mean that in terms of prices to the point of equilibrium how the rate of $\mathrm{Rp} 462.240$ and demand balance point stood at 36919 rooms. As an example of a 2-star hotel in Bandung, which was at least closer to the balance point is there are this two hotels:

1. Enhaii Hotel with price of Rp 464.000

2. Sanny Rossa by 36745 rooms demand
In the balance of demand and supply curves 3-star hotel in Bandung, obtained data on the balance point through polynomial regression method which can be explained as follows:

Polynomial Regression in Price

$$
\begin{gathered}
y=-1613.9 x^{2}+70786 x \\
R^{2}=-1.172
\end{gathered}
$$

Polynomial Regression in Demand

$$
\begin{gathered}
y=-67.261 x^{2}+3248.7 x \\
R^{2}=-0.113
\end{gathered}
$$

So the point of this balance may mean that in terms of prices for point balance stood at Rp. 633,000, - and demand balance point stood at 32718 rooms. As an example of a 3 -star hotel in Bandung, which was at least closer to the balance point is there are two hotels:

1 Bumi Sangkuriang with harga $\mathrm{Rp}$ 640,000

2 Ibis Style Braga by 32767 rooms demand 
Tabel 9

Level of Supply and Demand Balance 4 Star Hotel in Bandung

\begin{tabular}{clccc}
\hline $\begin{array}{c}\text { High Supply at } \\
\text { Low Demand }\end{array}$ & Hadiat's & 13505 & 2949 & 556 \\
\hline $\begin{array}{c}\text { High Supply at } \\
\text { High Demand }\end{array}$ & Pop Harris & 63875 & 100680 & -36805 \\
\hline $\begin{array}{c}\text { Low Supply at } \\
\text { High Demand }\end{array}$ & Fave Hotel & 54750 & 93097 & $: 347$ \\
\hline $\begin{array}{c}\text { Low Supply at } \\
\text { Low Supply }\end{array}$ & Hadiat's & 13505 & 12949 & 56 \\
\hline $\begin{array}{c}\text { Balance Point } \\
\text { (Equlibrium) }\end{array}$ & & $\mathbf{2 3 9 7 3}$ & $\mathbf{3 6 9 1 9}$ & $\mathbf{9 4 6}$ \\
\hline
\end{tabular}

In the balance of supply and demand curves 4-star hotel rooms in the city of Bandung, obtained data on the balance point through polynomial regression method which can be explained as follows:

Polynomial Regression in Price

$$
\begin{gathered}
y=-4326.1 x^{2}+128341 x \\
R^{2}=-0.866
\end{gathered}
$$

Polynomial Regression in Demand

$$
\begin{gathered}
y=-223.75 x^{2}+7093.8 x \\
R^{2}=-0.008
\end{gathered}
$$

So the point of this balance may mean that in terms of prices to the point of equilibrium how the rate of Rp782.880 and demand balance point stood at 45097 rooms. As an example of 4-star hotels in Bandung, which was at least closer to the balance point is there are two hotels:

1. Aston Primera with price of Rp 720.000

2. Novotel by 44963 rooms demand

\section{CONCLUSION}

1. Demand in 2-star hotel in Bandung is still high than the supply as much as 922963 rooms, compared with the 599330, there is gap of rooms available at -323633 room, and point of balance between demand and supply stood at 23973 rooms with prices deals publish Rp 462.240 from these results it can be stated that the 2-star hotel in Bandung still recommend to be build.

2. Demand for 3-star hotel in Bandung is relatively good there were $1,210,577$ room, compared with the 1.28188 million, the surplus of the number of rooms available at 71302 rooms, and point of balance between demand and supply stood at 34645 rooms with prices deals publish $\mathrm{Rp}$ 633.00 from these results it can be stated that the 3-star hotel in Bandung is quite a lot and is expected to be control the growth are expected not to disturb the balance of the market of another hotel classification .

3. Demand of 4-star hotels in Bandung is still high than there were $1,127,433$, rooms when compared with the number of rooms available for - 273688 rooms, and point of balance between supply and demand stands at 34149 rooms at a price of $\mathrm{Rp}$ 782.880 from these results it can be stated that the 4-star hotels in Bandung can be recommend to be build.

4. Based on the above findings which come to a conclusion that star hotel in Bandung may be replaced by other types of accommodation is seen from the figure the difference in the 2-star hotel in the city of Bandung can be transferred to the homestay market .

\section{REFERENCES}

[1] Rikunto, Suharsimi. 2008. Prosedur Penelitian Suatu Pendekatan Praktek. Jakarta : Rineka Cipta.

[2] Marbeta (2008). Dasar-Dasar Pengertian Hospitality dan Pariwisata. Bandung: PT. Alumni.

[3] Silalahi, Ulber. 2009. Metode Penelitian Sosial. Bandung. PT. Refika Aditama.

[4] Sugiyono. 2002. Metode Penelitian Administrasi. Bandung : CV Alfabeta.

[5] Undang-Undang RI No. 10 Tahun 2009. Tentang Aturan Pondok Wisata.

[6] United Nations Educational, Scientific, and Cultural Organization (2009).

[7] Sweeney, J. C., \& Soutar, G. N. (2001). Consumer Perceived Value: The Development of a Multiple Item Scale. Journal of Retailing 77(2), 203220. 
[8] Seubsamarn, K. 2009. Tourist Motivation to Use Homestays in Thailand and Their Satisfaction Based on The Destination's Cultural and Heritage-Based Attribute. (Online). Tersedia https://mospace.umsystem.edu/xmlui/bitstream/hand le/10355/5351/research.pdf, diakses November 2014.

[9] Husein Umar, 2003. Metode Riset Bisnis, Jakarta: PT Gramedia Pustaka.

[10] Suliyanto. 2010. Studi Kelayakan Bisnis: Pendekatan Praktis, Andi Offset, Yogyakarta.

[11] Wibowo. 2007. Manajemen Kinerja : Edisi 2. Jakarta : PT. Raja Grafindo Persada.

[12] Hessel, Nogi S.Tangkilisan. 2007. Manajemen Publik. Jakarta: Grasindo.
[13] Pearce dan Robinson. 2007. Manajemen Strategi. Jakarta : Salemba Empat

[14] Porter, Michael E.. 2007. Strategi Bersaing (competitive strategy). Tangerang : Kharisma Publishing Group.

[15] E.K. Valentin. 2001. "SWOT Analysis from a Resource-Based View". Journal of MarketingTheory and Practice. Weber State University.

[16] Lovelock, C \& J. Wirtz. 2007. Service Marketing : People, Technology, Strategy. $6^{\text {th }} \mathrm{ed}$. Upper Saddle River, NJ : Pearson Education International 